\title{
Goethes Urphänomen \\ und die platonische Idee
}

von

Elisabeth Rotten

Dr. phil.

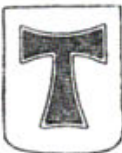

Gießen 1913

Verlag von Alfred Töpelmann (vormals J. Ricker) 
Philosophische Arbeiten

herausgegeben von

Hermann Cohen und Paul Natorp

in Berlin

in Marburg

VIII. Band 1. Heft 